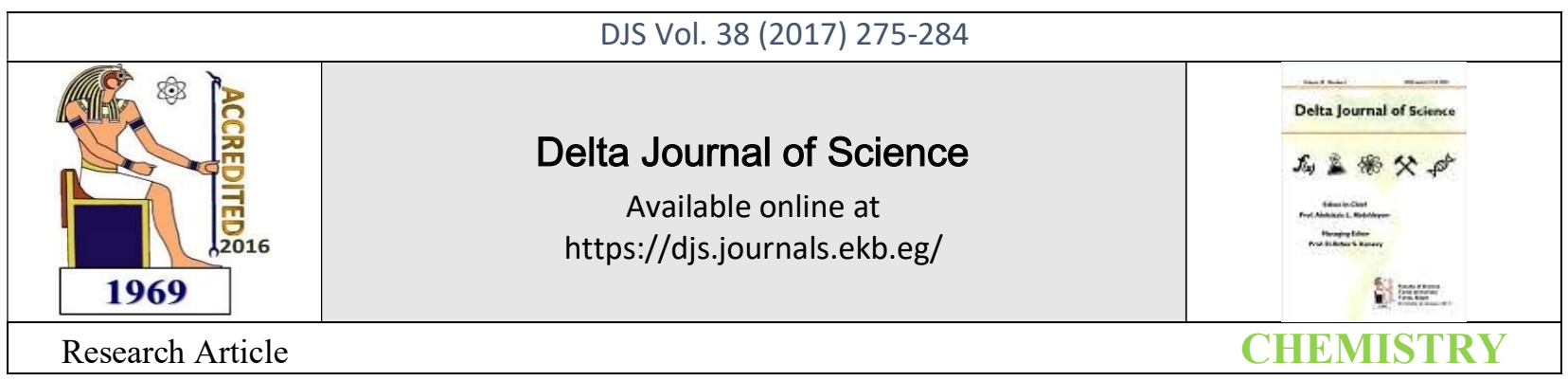

\title{
Copper and silver- (N,N'- bis [2-hydroxy-1- naphthylmethylidene] -1,2-diaminoethane) complexes as efficient catalysts for the formation of 1,4-disubstituted triazoles.
}

\author{
Safaa Eldin H. Etaiw*, Mohamed B. Elzarie and Marwa M. Rashad \\ Department of Chemistry, Faculty of Science, University of Tanta, 31527-Tanta, Egypt
}

\begin{abstract}
The reactions of copper and silver ions with N,N'-bis(2-hydroxy-1-naphthylmethylidene)1,2-diamino ethane (H2L) afford the complexes [CuL], 1 and [AgHL], 2. H2L and the complexes 1 and 2 were investigated by elemental analyses, molar conductance and spectral measurements. The elemental analysis data suggest the stoichiometric ratio 1:1 [M:L]. The molar conductance measurements reveal the presence of non-electrolytic nature of the complexes. Spectral data indicated the versatility of $\mathrm{H} 2 \mathrm{~L}$ as tetra-dentate ligand via $\mathrm{NONO}$ with $\mathrm{Cu}$ and $\mathrm{Ag}$ atoms forming square planar and tetrahedral geometries, respectively. These complexes have good catalytic activity in click reactions to prepare 1-benzyl -4- bromo triazole and 1-benzyl-4-phenyl triazole.Key words: click reaction, Cupper, Silver, supramolecular polymers, Catalysis.

Key words: Schiff base, Cupper, Silver, Complexes, Catalysis, Click reactions
\end{abstract}

\section{Introduction:}

C o -ordination compounds exhibit different characteristic properties which depend on the metal ion to which they are bound as well as the type of ligand, etc. These metal complexes have found extensive applications in various fields of human interest [1-3]. With increasing knowledge of the properties of functional groups, as well as the nature of donor atoms and the central metal ion, ligands with more selective chelating groups, i.e., imines or azomethanes, which are more commonly known as Schiff bases, are used for complex formation studies. Schiff bases play an important role in inorganic chemistry as they easily form stable complexes with most transition metal ions since they frequently exhibit unusual structural properties [4-6]. These properties have resulted in wide applications in different chemical fields [7-10]. The synthesis and characterization of extended bridged polymetallic complexes is a subject of great interest because of their potential applications in catalysis and materials chemistry [11-13]. Many binuclear complexes where the metal atoms are bridged by extended dicarboxylato ligands such as $\mu$ - terephthalate, $\mu$ oxalate, $\mu$-butene dicarboxylate have been reported [14-18]. Generally, Schiff-bases have played a seminal role in the development of modern coordination chemistry, but also they can be found at key points in the development of inorganic biochemistry, catalysis and optical materials. The Ag (I) ion is regarded as a soft acid that favors the coordination of soft bases, such as ligands that contain sulfur and unsaturated nitrogen. Complexes of silver (I) and N-heterocyclic ligands lead to the production of interesting geometric configurations and photophysical properties [19-21]. However, only a few examples of Ag (I)-containing Schiff-base complexes and coordination polymers have been studied in detail to date [22]. Copper (II) complexes show distorted octahedral and tetrahedral symmetries due to d9 configuration. The distortion is usually seen as axial elongation consistent with the lability and geometric flexibility of the complex [2326].

Therefore, typical Cu (II) complexes have square planar

or square pyramidal geometries with weakly associated

ligands in the axial positions, but some copper (II) complexes possess trigonal bipyramidal geometry [23-26].

The present work introduces the syntheses and characterization of a Schiff base ligand derived from 2hydroxy naphthaline -1-carbaldehyde and ethylenediamine and its $\mathrm{Ag}$ ı and Cuı complexes. These

complexes are prepared to be used as catalysts in 
bioconjugate areas have increased exponentially over the last decade [ 29 ].

\section{Experimental}

\subsection{Materials and instrumentation}

All chemicals used in this study were of the purest grade and used without further purification. Benzyl bromide [purity98\%], propagyl bromide [ $80 \%$ wt solution in toluene stabilized], phenylacetylene [purity 98\%] and $\mathrm{CuCL}_{2} \cdot 2 \mathrm{H}_{2} \mathrm{Owere}$ obtained from Acros. Sodium azide and sodium ascorbate [ASSay 99\%] were obtained from Universal fine chemicals. Dichloromethane [purity 99\%], diethyl ether, absolute ethyl alcohol [purity 98\%] and acetone [purity 98\%] were obtained from $\mathrm{Sd}$ fine chemical limited. Acetonitrile HPLC gradient grade was obtained from Fisher chemical. Thin-layer Chromatography [TLC] was carried out by using plastic sheets pre-coated with silica gel $60 \mathrm{~F}_{254}$ [Merck] and was visualized under $254 \mathrm{~nm}$ UV- light. Elemental analyses were performed on a Perkin-Elmer 2400 automatic elemental analyzer. The metal analysis was carried out by dissolving the substance by digestion the sample in $\mathrm{H}_{2} \mathrm{SO}_{4} / \mathrm{HNO}_{3}$. The oxidation of organic groups by $\mathrm{HNO}_{3}$ was completed when NO--fumes no more appeared then the metals were measured by Perkin-Elmer 5000 atomic absorption spectrophotometer. Infrared spectra were recorded on a Bruker vector 22 spectrophotometer applying $\mathrm{KBr}$ discs in the range of $4000-400 \mathrm{~cm}^{-1}$. Electronic absorption spectra in the visible and ultraviolet regions were measured on a Shimadzu 3101 PC spectrophotometer as a Nujol mull matrix. The magnetic susceptibility was determined with a Magnetic susceptibility balance 436 Devon Park Drive (USA) using $\mathrm{Hg}\left[\mathrm{Co}(\mathrm{SCN})_{4}\right]$ as calibrant. Molar conductivities measurements were carried out in DMSO using SybronBarnstead conduct meter (Meter-PM.6, E= 3406). The thermogravimetric analysis (TGA) was performed on Shimadzu AT-50 thermal analyzer in nitrogen atmosphere with heating rate $10 \circ \mathrm{C} / \mathrm{min}$.

\subsection{Syntheses}

2.2.1 Synthesis of Schiff base ligand (N, $N^{\prime}-$ bis [2hydroxy-1-naphthyl methylidene] -1,2-diaminoethane);

$\mathrm{H}_{2} \mathrm{~L}$

A hot solution $\left(60^{\circ} \mathrm{C}\right)$ of ethylenediamine [10 $\mathrm{mml}, 0.67$ $\mathrm{mL}$ ] was mixed with a hot solution $\left(60^{\circ} \mathrm{C}\right)$ of 2-hydroxy naphthaline -1-carbaldehyde [20 mml, $3.44 \mathrm{gm}$.] in $50 \mathrm{~mL}$ of ethanol. The resulting Mixture was left under reflux for $2 \mathrm{~h}$ and the solid yellow product formed was separated by filtration and washed by diethyl ether and ethanol.

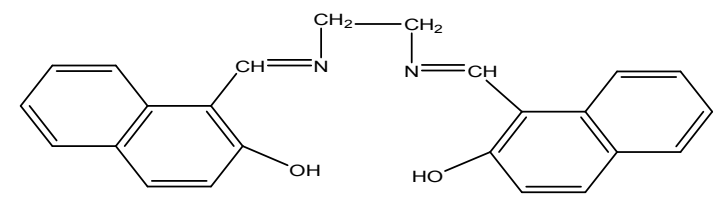

Scheme $1 \mathbf{N}, \mathbf{N}^{\prime}$ - bis [2-hydroxy-1-naphthyl methylidene] -1,2-diaminoethane

\subsubsection{Synthesis of Copper (II), 1, and Silver (I), 2,} Schiff base complexes

The complexes were prepared by the addition of a hot aqueous solution $\left(60^{\circ} \mathrm{C}\right)$ of the cupuric chloride $[2$ $\mathrm{mml}, 0.19 \mathrm{gm}$.] or silver nitrate [2 $\mathrm{mml}, 0.18 \mathrm{gm}$.] in an ethanol-water mixture $[1: 1,25 \mathrm{~mL}]$ to the hot solution of the Schiff base ligand [1 $\mathrm{mml}, 0.2 \mathrm{gm}$.] in the same solvent $[1: 1,25 \mathrm{~mL}]$. The resulting mixture was stirred under reflux for $1 \mathrm{~h}$ until the complex

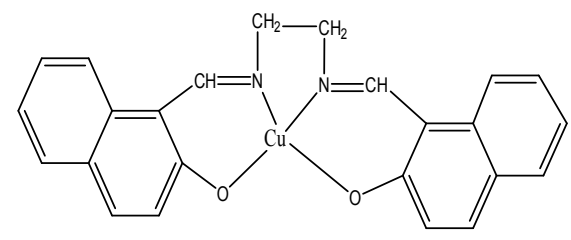

(1)

precipitated. The complexes $\mathrm{CuL}$ and AgHL were

collected by filtration and washed with $[1: 1]$ ethanolwater.

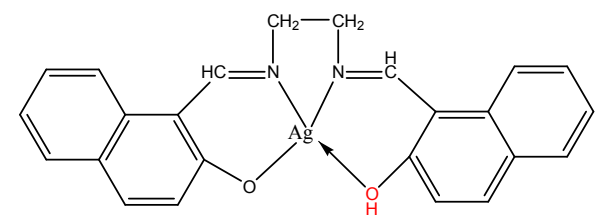

(2)

\section{Scheme 2 copper (1) and silver (2) - Schiff base} complexes

\subsubsection{Synthesis of benzyl azide}

Sodium azide (1.4 gm. , 2.5 equiv.) and Benzyl bromide ( $1 \mathrm{~mL}, 1.5$ equiv.) are dissolved in mixture of acetone and water $(1: 1,20 \mathrm{~mL})$ by stirring in $100 \mathrm{~mL}$ round - bottom flask under close system over night at room temperature, then leaving the mixture to evaporate acetone. The benzyl azide was extracted with water $(1 \times 10 \mathrm{~mL})$ and diethyl ether $(2 \times 10 \mathrm{~mL})$.
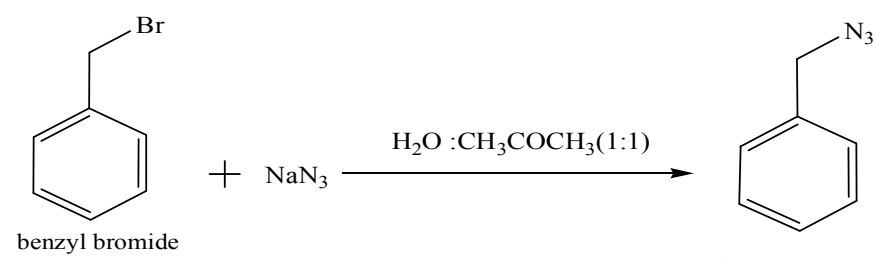

benzyl azid

\subsubsection{Synthesis of 1-benzyl- 4-bromo triazole}

Propagyl bromide (1 equiv. 0.09 gm.) and (2 equiv. 0.19 gm.), benzyl azide ( $(1$ equiv. $0.12 \mathrm{~mL})$ and (2 equiv. 0.25 $\mathrm{mL})$ and the catalyst $(0.025,0.05,0.1,0.15$ equiv.) were mixed in presence of acetonitrile and water mixture $(1: 1,20$ 
$\mathrm{mL}$ ). The mixture was stirred at room temperature or with gentle heating to deliver exclusively the corresponding 1,4 triazole<smiles>NCc1ccccc1</smiles><smiles>BCC#C</smiles>

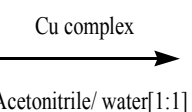

benzyl azid Propargyl bromide Acetonitrile/ water[1:1]

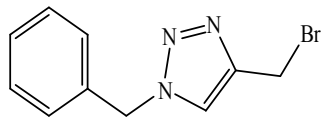
1-benzyl-4-(bromomethyl)-1H-1,2,3-
triazole<smiles>NCc1ccccc1</smiles><smiles>C#CCBr</smiles>

$\mathrm{A}$ Acetonitrile/ water[1:1]

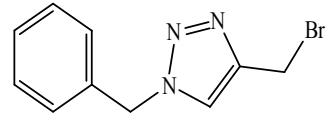

benzyl azid Propargyl bromide triazole

\subsubsection{Synthesis of 1-benzyl-4-phenyl triazole}

Phenyl acetylene (1 equiv. $0.1 \mathrm{~mL}$ ) and (2 equiv. $0.22 \mathrm{~mL}$ ), benzyl azide ( 1 equiv. $0.12 \mathrm{~mL}$ ) and ( 2 equiv. $0.25 \mathrm{~mL}$ ) and catalyst $(0.025,0.05,0.1,0.15$ equiv.) in presence of acetonitrile and water mixture $(1: 1,20 \mathrm{~mL})$ and stirring the mixture at room temperature or with gentle heating to deliver exclusively the corresponding 1,4-triazole .
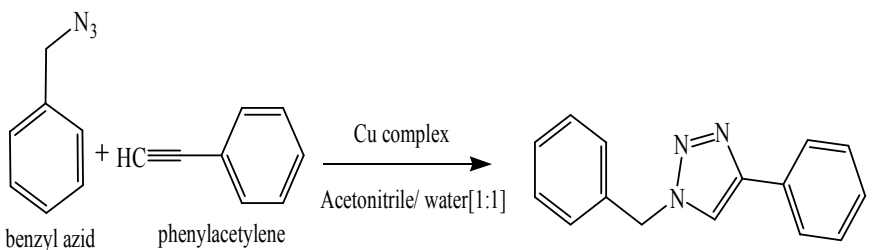

1-benzyl-4-phenyl-1H-1,2,3-triazole
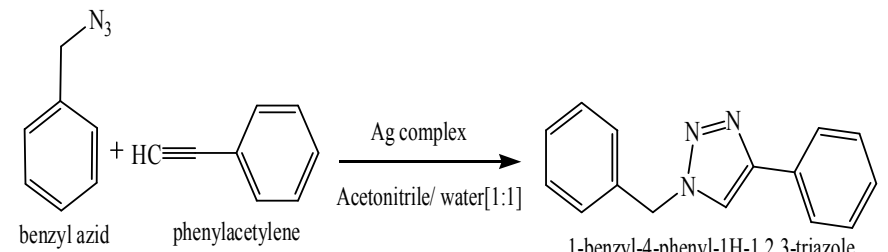

3 Results and Discussion

3.1 Characterization of Schiff base ligand and the complexes 1 and 2

The level of the purity of $\mathrm{H}_{2} \mathrm{~L}$ has been checked by running TLC on a silica gel coated plate using EtOAc$\mathrm{EtOH}(6: 4, \mathrm{v} / \mathrm{v})$ as the eluent. The elemental analysis data of the $\mathrm{H}_{2} \mathrm{~L}$ ligand and its copper and silver complexes agree well with the proposed compositions, Table 1. The isolated complexes are insoluble in common organic solvents but easily soluble in a mixture of acetonitrile- water mixture and DMF or DMSO. The molar conductance values of the complexes $\mathbf{1}$ and $\mathbf{2}$ fall in the range $6.7-8.3 \mathrm{ohm}^{-1} \mathrm{~mol}^{-1} \mathrm{~cm}^{2}$ indicating that the two complexes are non-electrolytes, Table 1 . The structure of the prepared Schiff-base ligand and its complexes $\mathbf{1}$ and $\mathbf{2}$ have been confirmed on the basis of analytical data, IR, electronic absorption spectra,

molecular modeling study, melting point, mass spectroscopy, thermal analysis and ${ }^{1} \mathrm{H}-\mathrm{NMR}$. The Agcomplex $\mathbf{2}$ is diamagnetic while the magnetic moment value of $\mathrm{Cu}$ (II)- complex 1 is $1.71 \mathrm{BM}$. This value is quite close the spin-only value of $1.73 \mathrm{BM}$ for $\mathrm{Cu}$ (II) [30]. This indicates the presence of single unpaired electron suggesting the square planer structure for the complex 1.

\subsection{Infrared spectra of Schiff base $\left(\mathrm{H}_{2} \mathrm{~L}\right)$ and its metal} complexes 1 and 2

The IR- spectra of the complexes $\mathbf{1}$ and $\mathbf{2}$ are compared with that of the free ligand $\mathrm{H}_{2} \mathrm{~L}$ in order to determine the coordination sites that may involve in chelation, Table 2 and Fig. 1. The band due to $v_{\mathrm{OH}}$ (phenolic) appears at $3427 \mathrm{~cm}^{-1}$ in the spectrum of $\mathrm{H}_{2} \mathrm{~L}$ which suffers shift to lower wavenumber; $3408 \mathrm{~cm}^{-1}$, supporting participation of oxygen atom of one hydroxyl group in the coordination sphere of the silver atom. On the other hand, this band disappears in the spectrum of the complex 1 indicating the covalent nature of the bond between the oxygen atoms and copper. The band due to $v_{\mathrm{C}=\mathrm{N}}$ of $\mathrm{H}_{2} \mathrm{~L}$ at $1641 \mathrm{~cm}^{-1}$ is shifted to lower wavenumbers (1623 and $1637 \mathrm{~cm}^{-1}$ ) in the spectra of complexes $\mathbf{1}$ and $\mathbf{2}$, respectively, indicating the participation of the azomethane nitrogen in coordination. New bands are found in the spectra of the complexes in the regions 505 and $518 \mathrm{~cm}^{-1}$, which are assigned to M-O stretching vibrations. The band at 477 and $441 \mathrm{~cm}^{-1}$ for 1 and 2, respectively, has been assigned to $\mathrm{M}-\mathrm{N}$ stretching vibrations indicating the participation of the azomethane nitrogen and oxygen atoms in the coordination sphere. Therefore, from the IR spectra, it is concluded that $\mathrm{H}_{2} \mathrm{~L}$ ligand behaves in different manners, according to nature and valence of the metal, as a mono- or bi-negative tetradentate ligand via the phenolic and the azomethane groups.

3.3The electronic absorption spectra of $\mathrm{H}_{2} \mathrm{~L}$ and its metal complexes 1 and 2

The UV-Vis absorption spectra of the maximum absorption wavelengths $\left(\lambda_{\max }\right)$ for $\mathrm{H}_{2} \mathrm{~L}$ and its complexes are listed in Table 3 and Fig. 2.The absorption spectrum of $\mathrm{H}_{2} \mathrm{~L}$ is characterized by five absorption bands while the spectra of $\mathbf{1}$ and $\mathbf{2}$ display four bands in the region of 200-450 nm. The first three bands resemble those observed in the spectra of naphthalene at 221, 286 and $312 \mathrm{~nm}$ [31]. Thus, the high intensity band at 212-225 $\mathrm{nm}$ can be attributed to ${ }^{1} \mathrm{~B}_{\mathrm{b}} \leftarrow{ }^{1} \mathrm{~A}$ transitions within the naphthyl moiety. The second and the third bands at 252$265 \mathrm{~nm}$ and $310-315 \mathrm{~nm}$ can be assigned to the ${ }^{1} \mathrm{~L}_{\mathrm{a}} \leftarrow{ }^{1} \mathrm{~A}$ and ${ }^{1} \mathrm{~L}_{\mathrm{b}} \leftarrow{ }^{1} \mathrm{~A}$ transitions within the naphthyl moiety, respectively. The fourth band in the spectrum of $\mathrm{H}_{2} \mathrm{~L}$ at $355 \mathrm{~nm}$ can be assigned to $\mathrm{n}-\pi^{*}$ transitions of the azomethane group which disappears in the spectra of $\mathbf{1}$ and $\mathbf{2}$ indicating participation of the azomethane group in coordination sphere of $\mathrm{Cu}$ and $\mathrm{Ag}$ atoms. The broad low energy band at 385-425 $\mathrm{nm}$ can be assigned to the charge transfer interaction involving the whole molecule. This band suffers blue shift due to participation of the nitrogen and oxygen atoms in complex formation.

3.4 NMR-spectra of $\mathrm{H}_{2} \mathrm{~L}$ and its metal complexes 1 and 2 
The $1 \mathrm{H}$ NMR spectra of the Schiff base ligand, $\mathrm{H}_{2} \mathrm{~L}$ and the complexes $\mathbf{1}$ and $\mathbf{2}$ are shown in Table 4 and Fig. 3. The ${ }^{1} \mathrm{H}-\mathrm{NMR}$ spectrum of $\mathrm{H}_{2} \mathrm{~L}$ shows sharp singlet at $9.175 \mathrm{ppm}$, corresponding to the hydroxyl protons which disappears on duteration. The multi signals within the range of 7.20-7.39 ppm are assigned to the aromatic protons of naphthyl rings. Also, the spectrum displays a sharp signal at 3.269 pmm corresponding to $\mathrm{CH}_{2}$ protons of the ethylene diamine bridge. In addition, the doublet at 8.029-8.054 ppm can be attributed to absorbance of the protons of the azomethane groups. The ${ }^{1} \mathrm{H}-\mathrm{NMR}$ spectrum of the $\mathrm{Cu}(\mathrm{II})$-complex, 1 was compared with that of the parent Schiff base, Fig. 3. The multiple signals of the naphthyl and azomethane protons appear as broad signals at 7.57-7.87and $8.52 \mathrm{ppm}$, respectively suggesting participation of the azomethane nitrogen in coordination with $\mathrm{Cu}(\mathrm{II})$. The disappearance of the $\mathrm{OH}$ signal at $9,175 \mathrm{ppm}$, in the spectrum of $\mathrm{H}_{2} \mathrm{~L}$ confirms involvement of the two anoinic oxygen atoms in the coordination sphere of $\mathrm{Cu}$ (II) atom. The signal of the $\mathrm{CH}_{2}$ protons appears at $3.31 \mathrm{ppm}$. On the other hand, the ${ }^{1} \mathrm{H}-\mathrm{NMR}$ spectrum of 2 displays the same signals of $\mathrm{H}_{2} \mathrm{~L}$. The presence of the $\mathrm{OH}$ signal at $9.152 \mathrm{ppm}$ indicates that only one $\mathrm{OH}$ group is ionized. The NMR-spectra support the formation of $\mathrm{N} 2 \mathrm{O} 2$ coordination sphere around the $\mathrm{Cu}(\mathrm{II})$ and $\mathrm{Ag}(\mathrm{I})$ atoms.

\subsection{Thermal analyses of $\mathrm{H}_{2} \mathrm{~L}$ and the metal complexes}

\section{1 and 2}

The thermal analysis of $\mathrm{H}_{2} \mathrm{~L}$ ligand takes place in three steps Table 5 and Fig. 4. The first step occurs from 121 to $306{ }^{\circ} \mathrm{C}$ and corresponds to the release of the one $\mathrm{OH}$ group [Obs. $17 \mathrm{~g} \mathrm{~mol}^{-1}$; Calcd $17 \mathrm{~g} \mathrm{~mol}^{-1}$ ]. This step is followed by the release of the $\left[\mathrm{C}_{14} \mathrm{H}_{13} \mathrm{~N}_{2} \mathrm{O}\right]$ fragment from 306 to $393{ }^{\circ} \mathrm{C}\left[\right.$ Obs. $225.216 \mathrm{~g} \mathrm{~mol}^{-1}$; Calcd . 225 $\left.\mathrm{g} \mathrm{mol}^{-1}\right]$. The third step from 393 to $999{ }^{\circ} \mathrm{C}$ corresponds to the release of $\left[\mathrm{C}_{10} \mathrm{H}_{6}\right]$ group [ Obs. $125.85 \mathrm{~g} \mathrm{~mol}^{-1}$; Calcd $\left.126 \mathrm{~g} \mathrm{~mol}^{-1}\right]$. Thus, $\mathrm{H}_{2} \mathrm{~L}$ ligand is stable up to 121 ${ }^{\circ} \mathrm{C}$. The complex $\mathbf{1}$ is stable up to $211{ }^{\circ} \mathrm{C}$ after which it starts decomposition via five stages of weight loss, Fig. 5. In this case, thermolysis starts by loss of the one oxygen atom from 211 to $342{ }^{\circ} \mathrm{C}$ [Obs. $16.3 \mathrm{~g} \mathrm{~mol}^{-1}$; Calcd $16 \mathrm{~g} \mathrm{~mol}^{-1}$ ]. This step is followed by removal of $\left[\mathrm{C}_{10} \mathrm{H}_{6} \mathrm{O}\right]$. The two steps are followed by the release of $\left[\mathrm{C}_{2} \mathrm{H}_{3} \mathrm{~N}\right]$ fragment at $380-536{ }^{\circ} \mathrm{C}$ and $536-740{ }^{\circ} \mathrm{C}$ [Obs. $41.2 \mathrm{~g} \mathrm{~mol}^{-1}$; Calcd $\left.41 \mathrm{~g} \mathrm{~mol}^{-1}\right]$. The last step corresponds to the release of the $\left[\mathrm{C}_{10} \mathrm{H}_{6}\right]$ fragment from 740 to $1000{ }^{\circ} \mathrm{C}$ [Obs. $126.2 \mathrm{~g} \mathrm{~mol}^{-1}$; Calcd $126 \mathrm{~g} \mathrm{~mol}^{-1}$ ]. The residue obtained in this case is coincident with copper. The decomposition of complex $\mathbf{2}$ takes place in four steps, Fig. 6. In this case, thermolysis starts by loss of the $\left[\mathrm{C}_{3} \mathrm{H}_{5} \mathrm{~N}\right.$ ] fragment from 129 to $319{ }^{\circ} \mathrm{C}$ [Obs. 54.69 $\mathrm{g} \mathrm{mol}^{-1}$; Calcd $\left.55 \mathrm{~g} \mathrm{~mol}^{-1}\right]$. This step is followed by release of the $\left[\mathrm{C}_{20} \mathrm{H}_{13} \mathrm{O}\right]$ fragment from 319 to $411^{\circ} \mathrm{C}$ [Obs. $269.04 \mathrm{~g} \mathrm{~mol}^{-1}$; Calcd $269 \mathrm{~g} \mathrm{~mol}^{-1}$ ]. Third step from 411 to $717^{\circ} \mathrm{C}$ corresponds to the release of [CHN] group [Obs. $27.04 \mathrm{~g} \mathrm{~mol}^{-1}$; Calcd $27 \mathrm{~g} \mathrm{~mol}^{-1}$ ]. The last step is the release of one oxygen atom from 717 to 999 ${ }^{\circ} \mathrm{C}$ [Obs. $16.1 \mathrm{~g} \mathrm{~mol}^{-1}$; Calcd $16 \mathrm{~g} \mathrm{~mol}^{-1}$ ]. The residue obtained in this case is coincident with silver. Thus, complex 2 is stable up to $129{ }^{\circ} \mathrm{C}$.

3.6 Molecular modeling
We performed cluster calculations using $\mathrm{DMOL}^{r}$ program [32] in Materials Studio package [33], which is designed for the realization of large scale density functional theory (DFT) calculations. DFT semi-core pseudopods calculations (dspp) were performed with the double numerica basis sets plus polarization functional (DNP). The DNP basis sets are of comparable quality to 6-31G Gaussian ba-sis sets [34]. Delley et al. showed that the DNP basis sets are more accurate than Gaussian basis sets of the same size [33]. The RPBE functional [35] is so far the best exchange-correlation functional [36] based on the generalized gradient approximation (GGA) which is employed to take account of the exchange and correlation effects of electrons. The geometric optimization is performed without any symmetry restriction. The geometric optimization is performed without any symmetry restriction. The molecular structure along with atom numbering and HOMO-LUMO representation of the complexes 1 and 2 are shown in Figs. 7 and 8..The $\mathrm{Cu}$ atoms acquire slightly distorted square plane geometry where $\mathrm{Cu} 29$ atom coordinates to two nitrogen and two oxygen atoms $\left(\mathrm{N}_{2} \mathrm{O}_{2}\right)$ forming two six and one five member rings. The bond lengths and bond angles are in the normal range reported for the proto-type compounds. The photoinduced charge redistribution over the whole molecular skeleton of the complexes 1 and 2 is well represented by plot of the Frontier molecular orbitals (HOMO and LUMO) as illustrated in Figs. 7 and $8(\mathrm{~b}, \mathrm{c})$. $\mathrm{E}_{\mathrm{HOMO}}$ is a quantum chemical descriptor which is often associated with the electron donating ability of the molecule. High value of $\mathrm{E}_{\mathrm{HOMO}}$ indicates a tendency of the molecule to donate electrons to appropriate acceptor molecule of low empty molecular orbital energy. However, $\mathrm{E}_{\mathrm{LUMO}}$ indicates the ability of the molecule to accept electrons. The HOMO electronic density distribution for the complex 1 can be represented as localization of charge density on the (N2O2-Cu) center, en fragment and $\mathrm{C} 1$, $\mathrm{C} 2, \mathrm{C} 6, \mathrm{C} 14, \mathrm{C} 16$ and $\mathrm{C} 24$ of the naphthyl moiety. In the case of LUMO level, the charge is mostly localized that can facilitate the donation from the ligand to $\mathrm{Cu} 29$ atom. Quantum chemical parameters for $1\left(\mathrm{E}_{\mathrm{HOMO}}, \mathrm{E}_{\mathrm{LUMO}}\right.$ and the energy gap, $\mathrm{DE}=\mathrm{E}_{\mathrm{LUMO}}-\mathrm{E}_{\mathrm{HOMO}}$ ) are found to be $4.794,-3.263$ and 1.531 e.v. respectively.

\subsection{Click reaction}

We reported here a homogeneous, well defined copper (II) complex 1 which is used as catalyst in click reaction. We prepared the1- benzyl - $4-$ [ bromomethyl] $-1 \mathrm{H}$ 1,2,3-triazole by adding the mixture of propagyl bromide [ Alkyne ], benzyl azide [ Azide ] and copper (II) complex [ catalyst ] in presence the sodium ascorbate to reduce the $\mathrm{Cu}$ (II) to $\mathrm{Cu}$ (I) in solvent acetonitrile and water at room temperature. Full conversion in yield [100\%] of azide /alkyne [2:1] to triazole required the use of [0.1 equivalent] of catalyst complex 1 within $1 \mathrm{~h}$ at room temperature [Table6; entry3]. Above reaction was occurred in the best condition because the triazole was formed in a short time and high yield. To check the efficiency of the catalyst 1 , this reaction was repeated two times on the initial catalyst by using identical quantities of azide / alkyne to provide [100\% yield] conversion within $2 \mathrm{~h}$ and $2: 30 \mathrm{~h}$ [Table 6; entries 
$5,6]$.Using 0.1 equivalent of catalyst complex 1 under otherwise conditions of [Table 6; entry 3] at $40^{\circ} \mathrm{C}$ and $60^{\circ} \mathrm{C}$. We observed that by increasing the temperature allowed conversion of azide / alkyne to triazole after $50 \mathrm{~min}$ and 20min [Table 6; entries 7, 8]. On the other hand, Using 0.1 equivalent of in case of silver (I) complex 2 as catalyst under the same conditions of the copper complex catalyst. It was observed that the silver catalyst 2 is the most efficient than the copper catalyst 1 [Table 7; entry3] because the triazole was formed after $30 \mathrm{~min}$ at room temperature.But when we were comparing these results with results of copper (II) acetate and silver nitrate, we observed that the triazole was formed after $4: 15 \mathrm{~h}$ and $25: 30 \mathrm{~h}$ [Table 8 ; compound 1,2 ] So , the copper and silver complexes 1 and 2 catalysis were more efficient catalysts than copper acetate and silver nitrate catalysis .On the other hand, when we used phenyl acetylene as alkyne instead of the propagyl bromide with benzyl azide and the complex 1 and 2 as a catalysts in the solvent of the acetonitrile and water [1:1] at room temperature to prepare 1-benzyl -4phenyl -1H-1,2,3-triazole. Full conversion in yield [100\%] of azide/alkyne [2:1] to triazole required 0.1 equivalent of catalyst complex 1 in presence of sodium ascorbate to reduce of $\mathrm{Cu}(\mathrm{II})$ to $\mathrm{Cu}(\mathrm{I})$ within $2: 15 \mathrm{~h}$ at room temperature [Table 9; entry 3]. Above reaction was occured in the best conditions because the triazole was formed in the short time and high yield. To check efficiency of the catalyst complex 1 , This reaction was repeated two times on the initial catalyst using the same quantities of azide/ alkyne to provide $100 \%$ conversion within $1: 30 \mathrm{~h}$ and $61 \mathrm{~min}$ [Table 9 ; entries 5,6] . Using 0.1 equivalent of catalyst complex 1 under other conditions of [Table 9; entry 3] at $40^{\circ} \mathrm{C}$ and $60^{\circ} \mathrm{C}$. We observed that by increasing the temperature allowed conversion of azide/alkyne to triazole after $25 \mathrm{~min}$ and $15 \mathrm{~min}$ [Table 9; entries 7, 8].On the other hand.using 0.1 equivalent of in case of silver (I) complex 2 as catalyst under the same conditions of the copper catalyst. It was observed that the silver catalyst 2 is the most efficient than the copper catalyst 1 [Table 10; entry 3] because the triazole was formed after $30 \mathrm{~min}$ at room temperature. But when we were comparing these results of copper (II) acetate and silver nitrate, we observed that the triazole was formed after $3: 30 \mathrm{~h}$ and $30 \mathrm{~h}$ [Table 11 ; compound 1,2$]$ so, the copper and silver complexes 1 and 2 catalysts are more efficient catalysts than the copper acetate and silver nitrate catalysts.

\section{References}

[1] N.V. Tverdova, E.D. Pelevina, N.I. Giricheva, G.V. Girichev, N.P. Kuzmina, O.V. Kotova, J. Mol. Struct. 1012 (2012) 151-161.

[2] K.Y. Lau, A. Mayr, K.K. Cheung, Inorg. Chim. Acta 285 (1999) 223.
[3] A.D. Garnovskii, I.S. Vasil Chenko, Russ. Chem. Rev. 71 (2002) 943-996

[4] C. Anitha, C. D. Sheela, P. Tharmaraj, S. Sumathi, Spectrochim. Acta, Part A 96 (2012) 493-500

[5] A. M. A. Alaghaz, B. A. El-Sayed, A. A. El-Henawy, R. A. A. Ammar, Mol. Struct. 1035 (2013) 83-93

[7] M. B. Halli, R. B. Sumathi, M. Kinni, Spectrochim. Acta, Part A 99 (2012) 46-56

[8] A. Chakraborty, P. Kumar, K. Ghosh, P. Roy, Eur. J. Pharmacol. 647 (2010) 1-12

[9] M. S. Alam, J. H. Choi, D. U. Lee, Med. Chem. 20 (2012) 4103-4108

[10] C. A. Wegermanna, P. Strapasson, S. M. M. Romanowski, A. Bortoluzzi, R. R. Ribeiro, F. S. Nunesa, S. M. Drechsel. App. Catalysis A: General 454 (2013) $11-20$

[11] A. M. A. Ibrahim, S. M. A. Al-Ashqar, Spectrochim. Acta, Part A 92 (2012) 238-244

[12] B. Tamami, S. Ghasemi. Appl. Catalysis A: General 393 (2011) 242-250

[13] P. M. Forster, A. K. Cheetham, Angew. Chem. Int. Ed Engl. 41 (2002) 457-459

[14] P. Ayyappan, O. R. Evans, W. Lin, Inorg. Chem. 40 (2001) 4627-4632

[15] S. S. Massoud, F. A. Mautner, R. Vicente, H. N. Sweeney, Inorg. Chim. Acta 359 (2006) 1489-1499

[16] F. A. Mautner, R. Vicente, F. R. Y. Louka, S. S. Massoud, Inorg. Chim. Acta 361(2008) 1339-1384

[17] S. S. Massoud, K. T. Broussard, F. A. Mautner, R. Vicente, M. K. Saha, I. Bernal, Inorg. Chim. Acta 361(2008) 123-131.

[18] L. Jiang, X. L. Feng,, T. B. Lu, Cryst. Growth Des 5(2005) 1469-1475.

[19](a) Catalano, V. J.; Kar, H. M.; Garnas, J. Angew. Chem., Int. Ed. 1999, 38, 1979-1982. (b) Zhang, G. q.; Yang, G. q.; Yang, L. y.; Chen, Q. q.; Ma, J. S. Eur. J. Inorg. Chem. 2005, 1919-1926. (c) Huang, X. C.; Zheng, S. L.; Zhang, J. P.; Chen, X. M. Eur. J. Inorg. Chem. 2004, 5, 1024-1029. (d) Ren, C. X.; Ye, B. H.; He, F.; Cheng, L.; Chen, X. M. CrystEngCommun 2004, 6, 200206.

[20] (a) Dong, Y.-B.; Cheng, J.-Y.; Ma, J.-P.; Huang, R.-Q.; Smith, M. D. Cryst. Growth Des. 2005, 5, 585591. (b) Catalano, V. J.; Malwitz, M. A. Inorg. Chem. 2003, 42, 5483-5485. (c) Kang, Y.; Seward, C.; Song, D.; Wang, S. Inorg. Chem. 2003, 42, 2789-2797. (d) Ouyang, X. M.; Liu, D. J.; Okamura, T. a.; Bu, H. W.; Sun, W. Y.; Tang, W. X.; Ueyama, N. Dalton Trans. 2003, 1836-1845. (e) Yam, V. W. W.; Lo, W. Y.; Zhu, N. Chem. Commun. 2003, 2446-2447.

[21] (a) Munakata, M.; Wu, L. P.; Kuroda-Sowa, T.; Maekawa, M.; Suenaga, Y.; Ning, G. L.; Kojima, T. J. Am. Chem. Soc. 1998, 120, 8610-8618. (b) Schmidbaur, H.; Bublak, W.; Huber, B.; Reber, G.; Muller, G. Angew. Chem., Int. Ed. Engl. 1986, 25, 1089-1090. (c) Che, C. M.; Yip, H. K.; Li, D.; Peng, S. M.; Lee, G. H.; Wang, Y. M.; Liu, S. T. J. Chem. Soc., Chem. Commun. 1991, 1615-1617. (d) Wu, C. D.; Ngo, H. L.; Lin, W. Chem. Commun. 2004, 1588-1589.

[22] (a) Liu, M.; Xu, G.; Liu, Y.; Chen, Q. Langmuir 2001, 17, 427-431. (b) Chen-jie, F.; Chun-ying, D.; Hong, M.; Cheng, H.; Qing-jin, M.; Yong-jiang, L.; Yu- 
hua, M.; Zhe-ming, W. Organometallics 2001, 20, 2525 2532. (c) Patra, G. K.; Goldberg, I. Cryst. Growth Des. 2003, 3, 321-329. (d) Hou, H.; Li, G.; Song, Y.; Fan, Y.; Zhu, Y.; Zhu, L. Eur. J. Inorg. Chem. 2003, 2325-2332. (e) Dong,

Y. B.; Zhao, X.; Huang, R. Q.; Smith, M. D.; zur Loye, H. C. Inorg. Chem. 2004, 43, 5603-5612. (f) Dong, Y. B.; Zhao, X.; Tang, B.; Wang, H. Y.; Huang, R. Q.; Smith, M. D.; zur Loye, H. C. Chem. Commun. 2004, 220-221.

[23] Rusere, L.N., Shalumova, T., Tanski, J.M., et al., Poly hedron, 2009, vol. 28, p. 3804.

[24] Pang, Y., Cui, S., Li, B., et al., Inorg. Chem., 2008, vol. 47 , p. 10317

[25]Giricheva, N.I., Giricheva, G.V., Kuzmina, N.P., et al., J. Struct. Chem., 2009, vol. 50, p. 52.

44, 686-698; e) K. A. Winans, C. R. Bertozzi, Chem. Biol. 1998, 5, R313-R315; f) K. J. Yarema, L. K. Mahal, R. E. Bruehl, E. C. Rodriguez, C. R. Bertozzi, J. Biol. Chem. 1998, 273, 31168-31179; g) E. Saxon, C. R. Bertozzi, Science 2000, 287, 2007-2010; h) Q. Wang, T. R. Chan, R. Hilgraf, V. V. Fokin, K. B. Sharpless, M. G. Finn, J. Am. Chem. Soc. 2003, 125, 3192-3193; i) R. Breinbauer, M. Kohn, ChemBioChem 2003, 4, 11471149; j) V. D. Bock, H. Hiemstra, J. H. Van Maarseveen, Eur. J. Org. Chem. 2006, 51-68; k) A. Wang, N. W. Nairn, R. S. Johnson, D. A. Tirrell, K. Grabstein, ChemBioChem 2008, 9, 324-330; 1) F. Amblard, J. H. Cho, R. F. Schinazi, Chem. Rev. 2009, 109, 4207-4220; m) T. Fekner, X. Li, M. M. Lee, M. K. Chan, Angew. Chem. 2009, 121, 1661; Angew. Chem. Int. Ed. 2009, 48, 1633-1635.

[30] F.A. Cotton, G. Wilkinson, C.A. Murillo, M. Bochmann, Advanced Inorganic Chemistry, sixth ed., Wiley, New York, 1999.
[26] Mouni, L., Akkurt, M., Yildirm, S.O., et al., J. Chem. Crystallogr., 2010, vol. 40, p. 169.

[27] Huisgen, R. 1.3-dipolare cycloadditionen ruckschau und ausblick. Angew. Chem. Int. Edit. 1963, $75,604-637$.

[28] Tornoe, C.W.; Christensen, C.; Meldal, M. Peptidotriazoles on solid phase: 1,2,3 -triazoles by regiospecific copper(I)-catalyzed 1,3-dipolar cycloadditions of terminal alkynes to azides. J. Org. Chem. 2002, 67, 3057-3064.

[29] For selective publications, see: a) Chem. Asian J. 2011, 6, 2568-2847 (thematic review issue); b) X. Li, Chem. Asian J. 2011, 6, 2606-2616; c) E. M. Sletten, C. R. Bertozzi, Acc. Chem. Res. 2011, 44, 666-676; d) M. D. Best, M. M. Rowland, H. E. Bostic, Acc. Chem. Res. 2011,

[31] H.H. Jalfe, M. Orechin, Theory and Applications of Ultraviolet Spectroscopy, 5th edn. (Wiley, New York, 1970)

[32] (i) B. Delley, J. Chem. Phys. 92 (1990) 508-517; (ii) B. Delley, Int. J. Quantum Chem. 69 (1998) 423433; (iii) B. Delley, J. Chem. Phys. 113 (2000) 77567764; (iv) X. Wu ana, A.K. Ray, Phys. Rev. B 65 (2002) 85403-85409;; (v) A. Kessi, B. Delley, Int. J. Quantum Chem. 68 (1998) 135-144.

[33] Materials Studio v 5.0 Copyright (2009). Accelrys Software Inc.

[34] W.J. Hehre, L. Radom, P.V.R. Schleyer, J.A. Pople, Initio Molecular Orbital Theory, John Wiley, New York, (1986).

[35] B. Hammer, L.B. Hansen, J.K. Nørskov, Phys. Rev. B 59 (1999) 7413-7421.

[36] A. Matveev, M. Staufer, M. Mayer, N. Rösch, Int. J. Quantum Chem. 75 (1999) 863-873.

Table 1 Analytical and physical data for the Schiff base $\mathrm{H}_{2} \mathrm{~L}$ and its complexes

\begin{tabular}{|c|c|c|c|c|c|c|c|c|}
\hline \multirow{2}{*}{ Compound } & \multirow{2}{*}{$\begin{array}{l}\text { Empirical } \\
\text { formula }\end{array}$} & \multirow{2}{*}{ Color } & \multirow{2}{*}{$\begin{array}{l}\text { Melting } \\
\text { point }\left({ }^{\circ} \mathrm{C}\right)\end{array}$} & \multicolumn{4}{|c|}{$\begin{array}{c}\text { Elemental Analysis } \\
\text { Found [Calc.] \% }\end{array}$} & \multirow{2}{*}{$\begin{array}{l}\text { Am ohm } \\
\mathrm{mol}^{-1} \mathrm{Cm}^{2}\end{array}$} \\
\hline & & & & $\% \mathrm{C}$ & $\% \mathrm{H}$ & $\% \mathrm{~N}$ & $\% \mathrm{M}$ & \\
\hline $\mathrm{H}_{2} \mathrm{~L}$ & $\mathrm{C}_{24} \mathrm{H}_{20} \mathrm{~N}_{2} \mathrm{O}_{2}$ & Yellow & $215-217$ & $\begin{array}{c}77.9 \\
{[78.13]}\end{array}$ & $\begin{array}{c}4.2 \\
{[4.19]} \\
\end{array}$ & $\begin{array}{c}6.8 \\
{[7.73]} \\
\end{array}$ & $-n$ & - \\
\hline 1 & $\mathrm{C}_{24} \mathrm{H}_{18} \mathrm{~N}_{2} \mathrm{O}_{2} \mathrm{Cu}$ & Deep green & $325-327$ & $\begin{array}{r}67.25 \\
{[67.05]} \\
\end{array}$ & $\begin{array}{c}4.0 \\
{[4.19]}\end{array}$ & $\begin{array}{c}6.4 \\
{[6.51]} \\
\end{array}$ & $\begin{array}{c}14.60 \\
{[14.78]}\end{array}$ & 8.3 \\
\hline 2 & $\mathrm{C}_{24} \mathrm{H}_{19} \mathrm{~N}_{2} \mathrm{O}_{2} \mathrm{Ag}$ & $\begin{array}{l}\text { Greenish } \\
\text { yellow }\end{array}$ & $300-302$ & $\begin{array}{c}60.39 \\
{[60.44]}\end{array}$ & $\begin{array}{c}3.9 \\
{[3.98]}\end{array}$ & $\begin{array}{c}5.60 \\
{[5.87]}\end{array}$ & $\begin{array}{c}22.87 \\
{[22.98]}\end{array}$ & 6.7 \\
\hline
\end{tabular}

Table 2 Characteristic IR vibrations $\left(\mathrm{cm}^{-1}\right)$ of $\mathrm{H}_{2} \mathrm{~L}$ ligand and the complexes, 1 and 2

\begin{tabular}{|c|c|c|c|c|c|c|c|c|c|}
\hline Compound & $\begin{array}{c}\text { v O- } \\
\mathrm{H}\end{array}$ & $\begin{array}{c}\text { v C-H } \\
\text { Aryl }\end{array}$ & $\begin{array}{c}\text { v C-H } \\
\text { Alkyl }\end{array}$ & v C=C & $\begin{array}{c}\text { v C- } \\
\mathbf{N}\end{array}$ & v C-O & $\begin{array}{c}\text { v } \\
\mathrm{C}=\mathrm{N}\end{array}$ & $\begin{array}{c}\text { v } \\
\mathrm{M} \leftarrow \mathrm{O}\end{array}$ & $\begin{array}{c}\text { v } \\
\mathrm{M} \leftarrow \mathrm{N}\end{array}$ \\
\hline $\mathrm{H}_{2} \mathrm{~L}$ & 3427 & 3044 & 2939 & $1539-1494$ & 1359 & 1259 & 1641 & - & - \\
\hline $\mathbf{1}$ & - & 3047 & 2935 & $1538-1509$ & 1350 & 1254 & 1623 & 518 & 477 \\
\hline $\mathbf{2}$ & 3408 & 3041 & 2937 & $1539-1493$ & 1357 & 1210 & 1637 & 505 & 441 \\
\hline
\end{tabular}


Table 3 Electronic absorption spectra of $\mathrm{H}_{2} \mathrm{~L}$ and the complexes 1 and 2

\begin{tabular}{|c|c|c|}
\hline compound & $\lambda_{\mathrm{abs}}(\mathrm{nm})$ & Assignment \\
\hline $\mathrm{H}_{2} \mathrm{~L}$ & $\begin{array}{l}212 \\
265 \\
310 \\
355 \\
425\end{array}$ & $\begin{array}{c}{ }^{1} \mathrm{~B}_{\mathrm{b}} \leftarrow{ }^{1} \mathrm{~A} \\
{ }^{1} \mathrm{~L}_{\mathrm{a}} \leftarrow{ }^{1} \mathrm{~A} \\
{ }^{1} \mathrm{~L}_{\mathrm{b}} \leftarrow{ }^{1} \mathrm{~A} \\
\mathrm{n}-\pi^{*} \\
\mathrm{C} \mathrm{T}\end{array}$ \\
\hline 1 & $\begin{array}{l}220 \\
255 \\
315 \\
---- \\
420\end{array}$ & $\begin{array}{c}{ }^{1} \mathrm{~B}_{\mathrm{b}} \leftarrow{ }^{1} \mathrm{~A} \\
{ }^{1} \mathrm{~L}_{\mathrm{a}} \leftarrow{ }^{1} \mathrm{~A} \\
{ }^{1} \mathrm{~L}_{\mathrm{b}} \leftarrow{ }^{1} \mathrm{~A} \\
\mathrm{n}-\pi^{*} \\
\mathrm{C} \mathrm{T}\end{array}$ \\
\hline 2 & $\begin{array}{l}225 \\
252 \\
310 \\
---- \\
385\end{array}$ & $\begin{array}{c}{ }^{1} \mathrm{~B}_{\mathrm{b}} \leftarrow{ }^{1} \mathrm{~A} \\
{ }^{1} \mathrm{~L}_{\mathrm{a}} \leftarrow{ }^{1} \mathrm{~A} \\
{ }^{1} \mathrm{~L}_{\mathrm{b}} \leftarrow{ }^{1} \mathrm{~A} \\
\mathrm{n}-\pi^{*} \\
\mathrm{CT}\end{array}$ \\
\hline
\end{tabular}

Table $4 \stackrel{1}{H}$ NMR spectral data of $\mathrm{H}_{2} \mathrm{~L}$ ligand and its complexes 1 and 2

\begin{tabular}{|c|c|c|c|c|c|}
\hline \multirow[b]{2}{*}{ Compound } & \multirow[b]{2}{*}{$\begin{array}{l}\text { TGA range } \\
\quad\left({ }^{\circ} \mathrm{C}\right)\end{array}$} & \multicolumn{2}{|c|}{ Mass loss } & \multirow[b]{2}{*}{ Assignment } & \multirow[b]{2}{*}{ Residue } \\
\hline & & $\begin{array}{c}\text { Calc. } \\
(\%)\end{array}$ & $\begin{array}{c}\text { Found } \\
(\%)\end{array}$ & & \\
\hline $\mathrm{H}_{2} \mathrm{~L}$ & $\begin{array}{l}121-306 \\
306-393 \\
393-999\end{array}$ & $\begin{array}{c}17 \\
225 \\
126 \\
\end{array}$ & $\begin{array}{c}17 \\
225.216 \\
125.85\end{array}$ & $\begin{array}{c}\mathrm{OH} \\
\mathrm{C}_{14} \mathrm{H}_{13} \mathrm{~N}_{2} \mathrm{O} \\
\mathrm{C}_{10} \mathrm{H}_{6}\end{array}$ & \\
\hline 1 & $\begin{array}{c}211-342 \\
342-380 \\
380-536 \\
536-740 \\
740-1000\end{array}$ & $\begin{array}{c}16 \\
142 \\
41 \\
41 \\
126 \\
\end{array}$ & $\begin{array}{c}16.3 \\
142.1 \\
41.2 \\
41.2 \\
126.2 \\
\end{array}$ & $\begin{array}{c}\mathrm{O} \\
\mathrm{C}_{10} \mathrm{H}_{6} \mathrm{O} \\
\mathrm{C}_{2} \mathrm{H}_{3} \mathrm{~N} \\
\mathrm{C}_{2} \mathrm{H}_{3} \mathrm{~N} \\
\mathrm{C}_{10} \mathrm{H}_{6}\end{array}$ & $\mathrm{Cu}$ \\
\hline 2 & $\begin{array}{l}129-319 \\
319-411 \\
411-717 \\
717-999\end{array}$ & $\begin{array}{c}55 \\
269 \\
27 \\
16\end{array}$ & $\begin{array}{c}54.69 \\
269.04 \\
27.04 \\
16.1\end{array}$ & $\begin{array}{c}\mathrm{C}_{3} \mathrm{H}_{5} \mathrm{~N} \\
\mathrm{C}_{20} \mathrm{H}_{13} \mathrm{O} \\
\mathrm{CHN} \\
\mathrm{O}\end{array}$ & $\mathrm{Ag}$ \\
\hline
\end{tabular}

Table 5 Thermogravimetric analysis (TGA) of $\mathrm{H}_{2} \mathrm{~L}$ and its metal complexes

\begin{tabular}{|c|c|c|c|c|}
\hline Compound & $\delta(\mathrm{CH}$-aliphatic $)$ & $\delta(\mathrm{CH}-\mathrm{Ar})$ & $\delta\left(\mathrm{CH}_{2}\right)$ & $\delta(\mathrm{OH})$ \\
\hline $\mathrm{H}_{2} \mathrm{~L}$ & $8.029-8.054$ & $7.2-7.739$ & 3.269 & 9.157 \\
\hline 1 & 8.523 & $7.574-7.873$ & 3.310 & - \\
\hline 2 & $8.02-8.052$ & $\begin{array}{c}7.173- \\
7.739\end{array}$ & 3.301 & 9.152 \\
\hline
\end{tabular}


Table 6 Optimization with Copper catalysis in the click reaction [benzyl azide $\backslash$ propagyl bromide]

\begin{tabular}{|c|c|c|c|c|c|c|}
\hline Entry & $\begin{array}{c}\text { Cat } \\
(\text { eq. })\end{array}$ & $\begin{array}{c}\text { Temp } \\
\left({ }^{\circ} \mathrm{C}\right)\end{array}$ & Azide & Alkyne & Time & Yield (\%) \\
\hline 1 & 0.025 & r.t & 2 & 1 & $3: 30 \mathrm{~h}$ & $100 \%$ \\
\hline 2 & 0.05 & r.t & 2 & 1 & $4: 15 \mathrm{~h}$ & $100 \%$ \\
\hline 3 & 0.1 & r.t & 2 & 1 & $1 \mathrm{~h}$ & $100 \%$ \\
\hline 4 & 0.15 & r.t & 2 & 1 & $2: 30 \mathrm{~h}$ & $100 \%$ \\
\hline 5 & 0.1 & r.t & 2.5 & 1.25 & $2 \mathrm{~h}$ & $100 \%$ \\
\hline 6 & 0.1 & r.t & 3 & 1.5 & $2: 30 \mathrm{~h}$ & $100 \%$ \\
\hline 7 & 0.1 & 40 & 2 & 1 & $50 \mathrm{~min}$ & $100 \%$ \\
\hline 8 & 0.1 & 60 & 2 & 1 & $20 \mathrm{~min}$ & $100 \%$ \\
\hline 9 & 0.1 & r.t & 1 & 1 & $1: 30 \mathrm{~h}$ & $100 \%$ \\
\hline 10 & 0.1 & r.t & 1 & 2 & $1: 14 \mathrm{~h}$ & $100 \%$ \\
\hline
\end{tabular}

Table 7 Optimization with silver catalysis in the click reaction [benzyl azide $\backslash$ propagyl bromide]

\begin{tabular}{|c|c|c|c|c|c|c|}
\hline Entry & Cat $(\mathrm{eq})$ & Temp $\left({ }^{\circ} \mathrm{C}\right)$ & Azide & Alkyne & Time & Yield \\
\hline 1 & 0.025 & r.t & 2 & 1 & $2 \mathrm{~h}$ & $100 \%$ \\
\hline 2 & 0.05 & r.t & 2 & 1 & $2: 22 \mathrm{~h}$ & $100 \%$ \\
\hline 3 & 0.1 & r.t & 2 & 1 & $30 \mathrm{~min}$ & $100 \%$ \\
\hline 4 & 0.15 & r.t & 2 & 1 & $2 \mathrm{~h}$ & $100 \%$ \\
\hline 5 & 0.1 & r.t & 2.5 & 1.25 & $40 \mathrm{~min}$ & $100 \%$ \\
\hline 6 & 0.1 & r.t & 3 & 1.5 & $1 \mathrm{~h}$ & $100 \%$ \\
\hline 7 & 0.1 & 40 & 2 & 1 & $27 \mathrm{~min}$ & $100 \%$ \\
\hline 8 & 0.1 & 60 & 2 & 1 & $20 \mathrm{~min}$ & $100 \%$ \\
\hline 9 & 0.1 & r.t & 1 & 1 & $45 \mathrm{~min}$ & $100 \%$ \\
\hline 10 & 0.1 & r.t & 1 & 2 & $2: 30 \mathrm{~h}$ & $100 \%$ \\
\hline
\end{tabular}

Table 8 Using Copper Acetate(1) and silver nitrate (2) as catalyst with benzyl azide and propagyl bromide

\begin{tabular}{|c|c|c|c|c|c|}
\hline Compound & Cat (eq) & Azide & Alkyne & Time & yield \\
\hline 1 & 0.1 & 2 & 1 & $4: 15 \mathrm{~h}$ & $100 \%$ \\
\hline 2 & 0.1 & 2 & 1 & $25: 30 \mathrm{~h}$ & $100 \%$ \\
\hline
\end{tabular}

Table 9 Optimization with Copper catalyst 1 in the click reaction [benzyl azidelphenyl acetylene]

\begin{tabular}{|c|c|c|c|c|c|c|}
\hline Entry & Cat (eq) & Temp $\left({ }^{\circ} \mathrm{C}\right)$ & Azide & Alkyne & Time & Yield \\
\hline 1 & 0.025 & r.t & 2 & 1 & $2: 13 \mathrm{~h}$ & $100 \%$ \\
\hline 2 & 0.05 & r.t & 2 & 1 & $1: 20 \mathrm{~h}$ & $100 \%$ \\
\hline 3 & 0.1 & r.t & 2 & 1 & $30 \mathrm{~min}$ & $100 \%$ \\
\hline 4 & 0.15 & r.t & 2 & 1 & $1 \mathrm{~h}$ & $100 \%$ \\
\hline 5 & 0.1 & r.t & 2.5 & 1.25 & $1 \mathrm{~h}$ & $100 \%$ \\
\hline 6 & 0.1 & r.t & 3 & 1.5 & $1: 15 \mathrm{~h}$ & $100 \%$ \\
\hline 7 & 0.1 & 40 & 2 & 1 & $27 \mathrm{~min}$ & $100 \%$ \\
\hline 8 & 0.1 & 60 & 2 & 1 & $20 \mathrm{~min}$ & $100 \%$ \\
\hline 9 & 0.1 & r.t & 1 & 1 & $3: 14 \mathrm{~h}$ & $100 \%$ \\
\hline 10 & 0.1 & r.t & 1 & 2 & $62 \mathrm{~min}$ & $100 \%$ \\
\hline
\end{tabular}


Table 10 Optimization with silver catalyst 2 in the click reaction [benzyl azidelphenyl acetylene]

\begin{tabular}{|c|c|c|c|c|c|}
\hline Compound & Cat(eq) & Azide & Alkyne & Time & Yield \\
\hline 1 & 0.1 & 2 & 1 & $3: 30 \mathrm{~h}$ & $100 \%$ \\
\hline 2 & 0.1 & 2 & 1 & $30 \mathrm{~h}$ & $100 \%$ \\
\hline
\end{tabular}

Table 11 Using copper acetate (1) and silver nitrate (2) as catalyst with benzyl azide and phenyl acetylene

\section{Figures}

\begin{tabular}{|c|c|c|c|c|c|c|}
\hline Entry & Cat (eq) & Temp $\left({ }^{\circ} \mathbf{C}\right)$ & Azide & Alkyne & Time & Yield \\
\hline $\boldsymbol{1}$ & 0.025 & r.t & 2 & 1 & $2: 30 h$ & $100 \%$ \\
\hline $\mathbf{2}$ & 0.05 & .t & 2 & 1 & $4 h$ & $100 \%$ \\
\hline $\mathbf{3}$ & 0.1 & r.t & 2 & 1 & $2: 15 h$ & $100 \%$ \\
\hline $\mathbf{4}$ & 0.15 & r.t & 2 & 1 & $3: 30 h$ & $100 \%$ \\
\hline $\mathbf{5}$ & 0.1 & r.t & 2.5 & 1.25 & $1: 30 h$ & $100 \%$ \\
\hline $\mathbf{6}$ & 0.1 & r.t & 3 & 1.5 & $61 \mathrm{~min}$ & $100 \%$ \\
\hline $\boldsymbol{7}$ & 0.1 & 40 & 2 & 1 & $25 \mathrm{~min}$ & $100 \%$ \\
\hline $\boldsymbol{8}$ & 0.1 & 60 & 2 & 1 & $15 \min$ & $100 \%$ \\
\hline $\mathbf{9}$ & 0.1 & r.t & 1 & 1 & $2: 40 h$ & $100 \%$ \\
\hline $\mathbf{1 0}$ & 0.1 & r.t & 1 & 2 & $2: 35 h$ & $100 \%$ \\
\hline
\end{tabular}

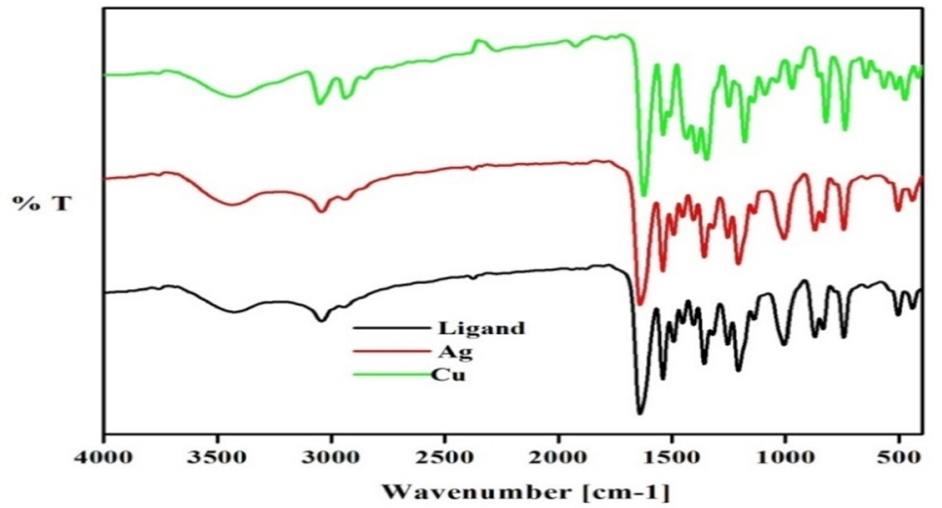

Figure 1 The IR spectrum of $\mathbf{H}_{\mathbf{2}} \mathbf{L}$ ligand and the complexes 1 and 2

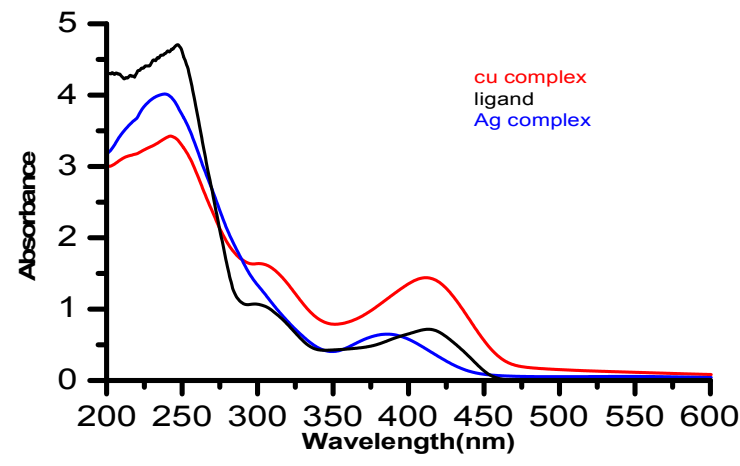

Figure 2 Electronic absorption spectra of schiff base ligand and the complexes $\mathbf{1}$ and $\mathbf{2}$

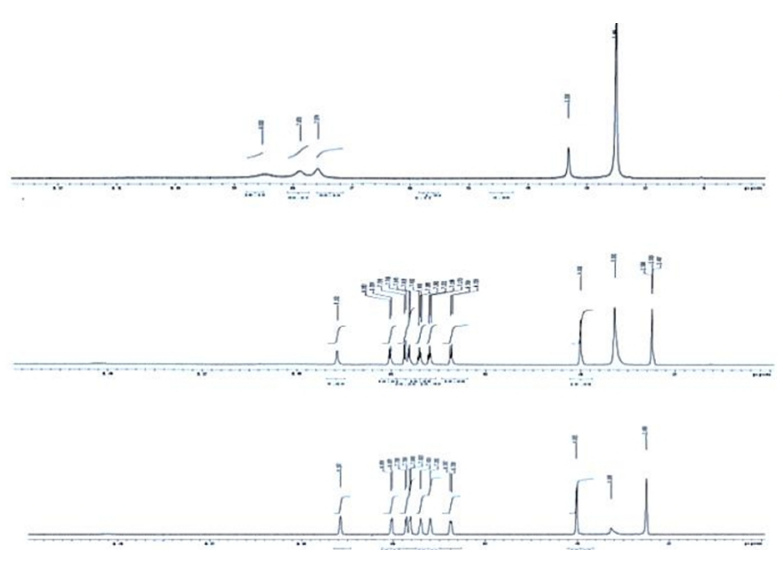

Figure $3{ }^{1} \mathrm{H}-\mathrm{NMR}$ spectrum of $\mathrm{H}_{2} \mathrm{~L}$ ligand Schiff base complexes 1 and 2

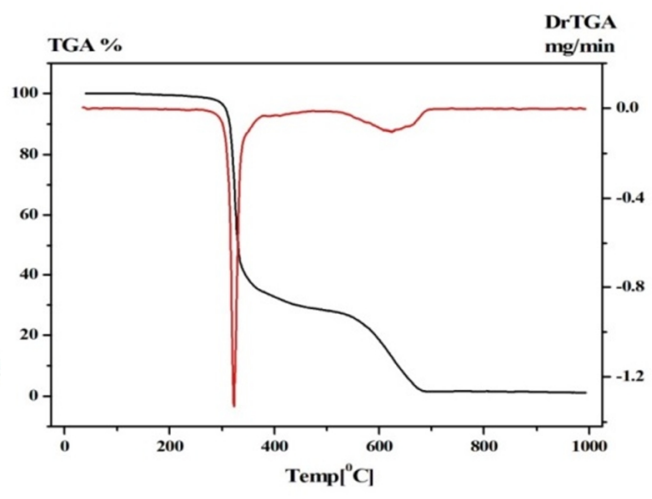

Figure 4 TGA and DTG curves of and the $\mathrm{H}_{2}$ Lligand 

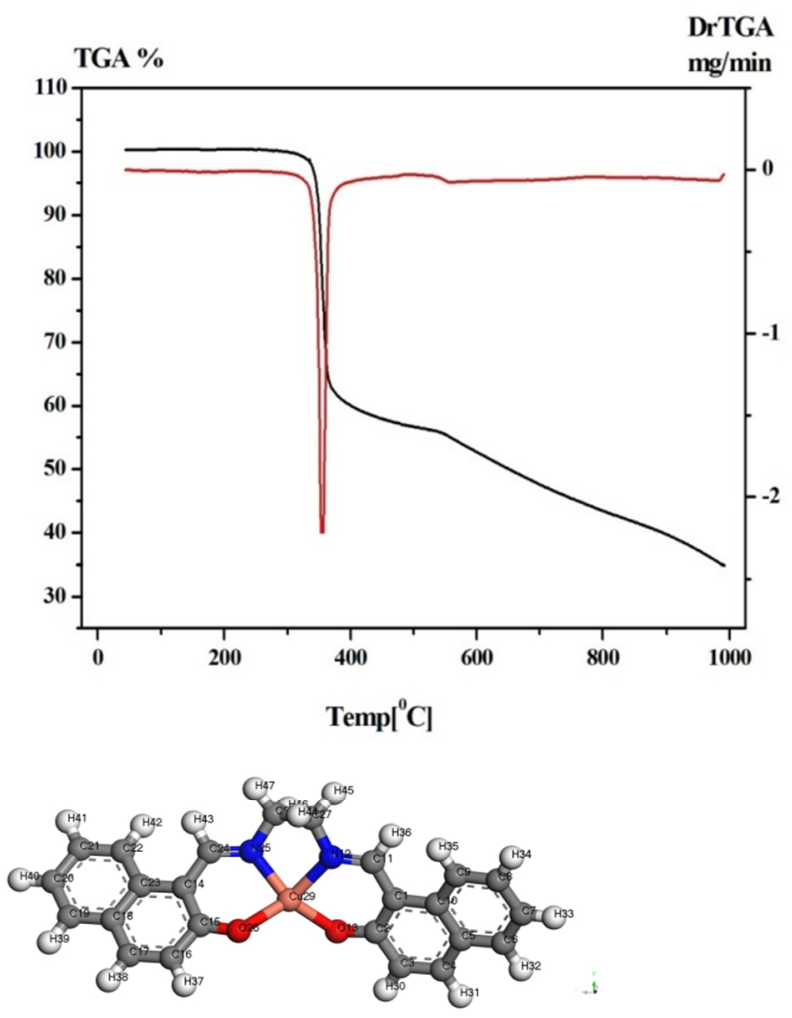

$\mathrm{Cu}$ - complex, (a)

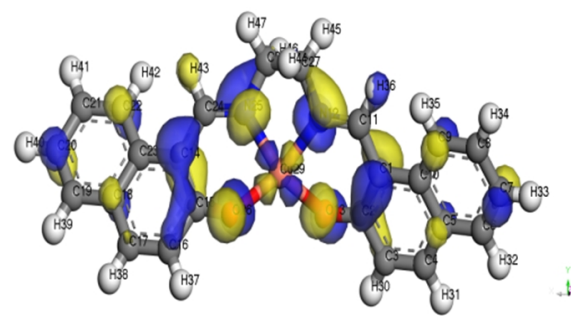

$\mathrm{Cu}-\mathrm{HOMO},(\mathrm{b})$

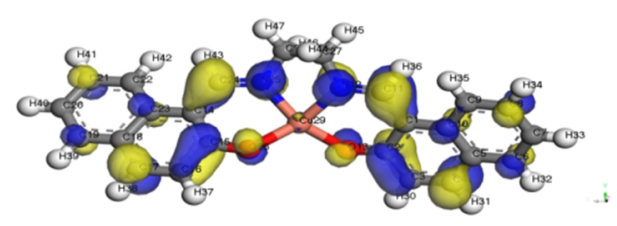

$\mathrm{Cu}-\mathrm{LUMO},(\mathrm{c})$

Figure 7 (a)Optimized geometry of complex 1, (b,c) HOMO-LUMO representation of 2

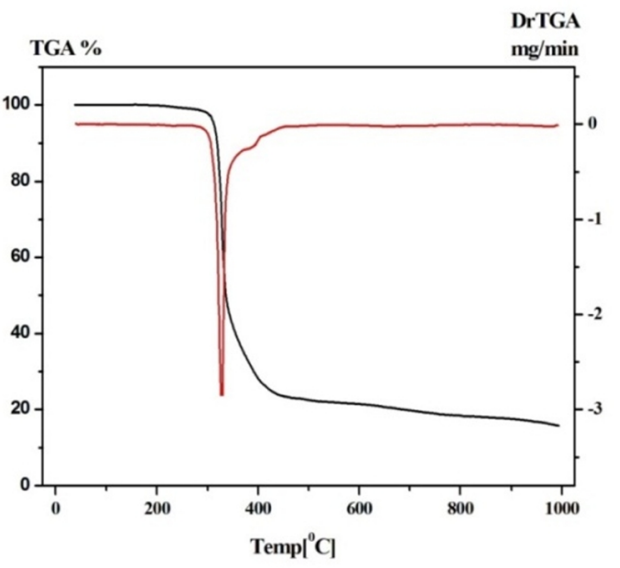

Figure 5 TGA and DTG curves of complex 1 Figure 6 TGA and DTG curves of complex 2

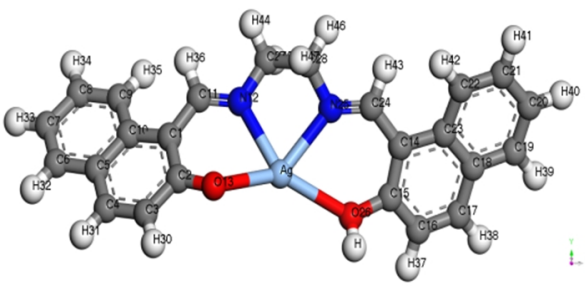

Ag Complex, (a)

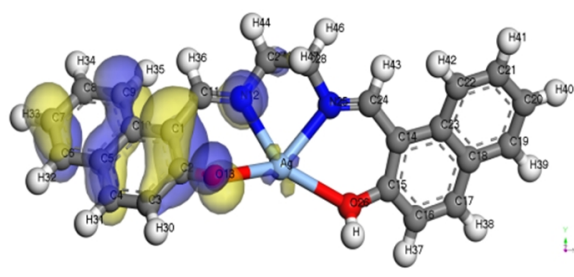

Ag HOMO, (b)

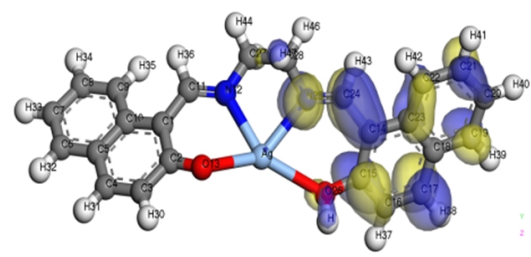

Ag- LUMO, ( c)

Figure 8 (a) Optimized geometry of complex 2 , (b,c) HOMO-LUMO representation of 1

متر اكبات النحاس و الفضة لمشتقات ثنائى الأمين كعو امل حفازة للحصول على ا،ــ ثنائى الإستبدال للتر ایى آزول

تحضير متر اكبات النحاس و الفضة لثنائى الأمين و إستعمالها كعو امل حفازة لتفاعلات كيمبائية محدده ودر اسة كاملة لخصائص هذه

المتر اكبات ـ الإستفادة من هذه المتر اكبات كعو امل حفازه تجاه تفاعلات الإضافية الحلقية التى تحتوى على الآزيد و الألكاين بالمقارنة

مع أملاح اسيتات النحاس او نترات الفضة و التى تستخدم فى تكوين التفاعلات الإضافة الحلقية للحصول على (،ــ ثنائى الإستبدال 